\title{
Fine particle size and enzyme supplementation as factors improving utilization of protein from diets with lowered protein contents by pigs
}

\author{
M. Flis ${ }^{1}$ and W. Sobotka \\ University of Warmia and Mazury in Olsztyn, \\ Department of Animal and Feed Management \\ Oczapowskiego 5, 10 -718 Olsztyn, Poland
}

\begin{abstract}
Thirty-two crossbred barrows were fed from about 28 to $100 \mathrm{~kg}$ body weight on a coarsely ground $(800 \mu \mathrm{m})$ diet with a standard protein content (diet C), and on two finely ground $(500 \mu \mathrm{m})$ diets with protein contents lowered by $8 \%$, with or without supplementation with glucanase and xylanase (diets F and FE, respectively). Fine grinding (diet F vs C) and enzyme supplementation (diet FE vs F) increased protein digestibility, while grinding also increased energy digestibility. Pigs fed the F and FE diets excreted less nitrogen and retained the same amount of nitrogen as animals on diet C. Daily gains, feed utilization, carcass leanness, and fat and protein contents in Musculus longissimus dorsi were not significantly affected by treatment. Protein conversion was better in groups $\mathrm{F}$ and $\mathrm{FE}$ than in $\mathrm{C}$.
\end{abstract}

KEY WORDS: particle size, enzymes, growth, digestibility, nitrogen balance, pigs

\section{INTRODUCTION}

The feed industry applies several methods to increase the nutritional value of feed mixtures, including milling and enzyme supplementation. The reduction of feed particle size increases the surface area exposed to digestive enzymes, thus improving absorption of nutrients (Wondra et al., 1995; Oryschak at al., 2002). The addition of enzymes that hydrolyse non-starch polysaccharides in cereal grains also increases the digestibility of nutrients (Baidoo et al., 1998). However, particle size reduction or enzyme supplementation may fail to increase the performance of pigs when the dietary contents of crude protein, amino acids and energy are not reduced (Mavromichalis et al., 2000).

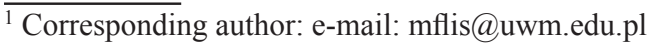


The objective of the experiment was to evaluate the effects of fine grinding and addition of $\beta$-glucanase and xylanase as factors improving protein utilization from diets with a lowered protein level that contributes to decreasing nitrogen excretion by growing-finishing pigs.

\section{MATERIAL AND METHODS}

A growth experiment was carried out on 32 crossbred castrated males fed individually on grower (28.5-65.2 kg body weight (BW) and finisher (65.2-99.7 $\mathrm{kg} \mathrm{BW})$ diets. Three diets were prepared: a coarsely ground $(800 \mu \mathrm{m})$ control diet formulated according to Polish standards (diet C), a finely ground $(500 \mu \mathrm{m})$ diet with an $8 \%$ lower protein content (diet F), and $\operatorname{diet} \mathrm{F}$ supplemented with $\beta$-glucanase and xylanase (Porzyme 9100) (diet FE) (Table 1). Diets were fed in wet form in daily rations increased from 1.6 to $3.0 \mathrm{~kg}$, water was given ad libitum after the meals. A 6-day balance experiment was carried out on 17 pigs of mean BW $55.3 \mathrm{~kg}$ to determine protein and energy digestibility and nitrogen (N) retention. Meat content in the carcass and fat and protein content in Musculus longissimus dorsi were determined after slaughter at $100 \mathrm{~kg} \mathrm{BW}$.

Table 1 . Formulation and nutritional value of the diets, $\mathrm{g} \cdot \mathrm{kg}^{-1}$

\begin{tabular}{|c|c|c|c|c|c|c|}
\hline \multirow{2}{*}{ Item } & \multicolumn{3}{|c|}{ Grower diet } & \multicolumn{3}{|c|}{ Finisher diet } \\
\hline & $\mathrm{C}$ & $\mathrm{F}$ & FE & $\mathrm{C}$ & $\mathrm{F}$ & FE \\
\hline Barley & 553.4 & 577.2 & 576.2 & 676.7 & 696.4 & 695.4 \\
\hline Wheat & 250.0 & 260.0 & 260.0 & 200.0 & 210.0 & 210.0 \\
\hline Soyabean meal & 164.0 & 129.0 & 129.0 & 96.0 & 65.0 & 65.0 \\
\hline Minerals & 25.0 & 26.0 & 26.0 & 20.0 & 21.0 & 21.0 \\
\hline Trace mineral-vitamin premix ${ }^{1}$ & 5.0 & 5.0 & 5.0 & 5.0 & 5.0 & 5.0 \\
\hline L-lysine $\mathrm{HCl}$ & 2.0 & 2.2 & 2.2 & 1.9 & 2.2 & 2.2 \\
\hline DL-methionine & 0.6 & 0.6 & 0.6 & 0.4 & 0.4 & 0.4 \\
\hline Porzyme $9100^{2}$ & - & - & 1.0 & - & - & 1.0 \\
\hline \multicolumn{7}{|l|}{ Nutritional value } \\
\hline crude protein (analysed) & 169 & 157 & 155 & 149 & 138 & 138 \\
\hline lysine & 9.3 & 8.5 & 8.5 & 7.7 & 7.1 & 7.1 \\
\hline methionine & 3.0 & 2.8 & 2.8 & 2.5 & 2.3 & 2.3 \\
\hline $\mathrm{ME}, \mathrm{MJ} / \mathrm{kg}$ & 12.5 & 12.5 & 12.5 & 12.5 & 12.5 & 12.5 \\
\hline Mean particle size, $\mu \mathrm{m}$ & 812 & 516 & 512 & 818 & 528 & 521 \\
\hline
\end{tabular}

${ }^{1}$ premix on ground limestone carrier, containing $1 \mathrm{~g} / \mathrm{kg}$ flavomycin

${ }^{2}$ enzyme preparation containing $400 \mathrm{U} / \mathrm{g} \beta$-glucanase and $400 \mathrm{U} / \mathrm{g}$ ksylanase

\section{RESULTS AND DISCUSSION}

Both fine grinding and enzyme supplementation of the finely ground diet increased the digestibility of crude protein to the same extent (by $2.8 \% ; \mathrm{P}<0.01$; Table 2). The digestibility of gross energy was slightly more affected by the fine grinding than by the enzyme supplementation (group F vs $\mathrm{C} ; \mathrm{P}<0.01$, and $\mathrm{FE}$ vs 
F; $\mathrm{P}<0.05)$. Pigs fed the finely ground diets with a lower protein content excreted less $(\mathrm{P}<0.01) \mathrm{N}$ and retained daily the same amount of $\mathrm{N}$ as those fed the coarsely ground diet with a higher protein content. Enzyme supplementation of diet FE did not increase $\mathrm{N}$ retention or the $\mathrm{N}$ retained/ $\mathrm{N}$ intake ratio.

Table 2. Balance and growth experiment $(28.5-99.7 \mathrm{~kg})$ results and carcass characteristics

\begin{tabular}{|c|c|c|c|c|c|}
\hline \multirow{2}{*}{ Item } & \multicolumn{3}{|c|}{ Diet } & \multirow{2}{*}{ SEM } & \multirow{2}{*}{$\begin{array}{c}\mathrm{P} \\
\text { value }\end{array}$} \\
\hline & C & $F$ & FE & & \\
\hline \multicolumn{6}{|l|}{ Balance experiment } \\
\hline crude protein digestibility, $\%$ & $77.4^{\mathrm{C}}$ & $79.6^{\mathrm{B}}$ & $81.8^{\mathrm{A}}$ & 0.486 & $<0.01$ \\
\hline energy digestibility, $\%$ & $81.5^{\mathrm{cB}}$ & $83.2^{\mathrm{bA}}$ & $84.4^{\mathrm{aA}}$ & 0.349 & $<0.01$ \\
\hline $\mathrm{N}$ intake, $\mathrm{g} /$ day & 62.23 & 57.74 & 57.15 & - & - \\
\hline $\mathrm{N}$ excreted, g/day & $35.04^{\mathrm{A}}$ & $30.83^{\mathrm{B}}$ & $30.41^{\mathrm{B}}$ & 0.617 & $<0.01$ \\
\hline $\mathrm{N}$ retained, $\mathrm{g} /$ day & 27.19 & 26.91 & 26.74 & 0.358 & 0.890 \\
\hline $\mathrm{N}$ retained, $\%$ of intake & 43.7 & 46.6 & 46.8 & 0.685 & 0.137 \\
\hline \multicolumn{6}{|l|}{ Growth experiment } \\
\hline initial body weight, $\mathrm{kg}$ & 28.09 & 29.60 & 27.82 & 0.525 & 0.352 \\
\hline final body weight, $\mathrm{kg}$ & 98.86 & 100.25 & 100.04 & 0.629 & 0.637 \\
\hline average daily gain, $g$ & 827 & 832 & 854 & 8.35 & 0.363 \\
\hline feed conversion ratio, $\mathrm{kg} / \mathrm{kg}$ & 2.96 & 2.94 & 2.85 & 0.033 & 0.360 \\
\hline crude protein conversion, $\mathrm{g} / \mathrm{kg}$ & $467^{\mathrm{A}}$ & $432^{\mathrm{B}}$ & $415^{\mathrm{B}}$ & 6.23 & $<0.01$ \\
\hline carcass meat, $\%$ & 53.26 & 52.67 & 52.60 & 0.634 & 0.899 \\
\hline protein in $l$. dorsi muscle, $\%$ & 23.55 & 23.28 & 23.29 & 0.114 & 0.543 \\
\hline fat in $l$. dorsi muscle, $\%$ & 1.64 & 1.79 & 1.84 & 0.077 & 0.552 \\
\hline
\end{tabular}

a,b,c- $\mathrm{P}<0.05$; ${ }^{\mathrm{A}, \mathrm{B}, \mathrm{C}}-\mathrm{P}<0.01$

Pigs fed the finely ground diet containing less protein $(\mathrm{F})$ had similar daily gains and feed utilization as those fed the control diet with a higher protein content, but coarsely ground. The supplementation of diet FE with $\beta$-glucanase and xylanase tended to increase daily gains and feed utilization (by 2.6 and $3.1 \%$, respectively). Pigs fed diets $\mathrm{F}$ and FE used less crude protein per $\mathrm{kg}$ body gain than those fed diet C (432 and $415 \mathrm{vs} 467 \mathrm{~g} / \mathrm{kg} ; \mathrm{P}<0.01$ ). Decreasing the crude protein content by $8 \%$ in the finely ground diet, used with or without enzyme supplementation, did not lower carcass meatiness or the protein and fat content in the $l$. dorsi muscle.

The increased digestibility of protein and energy as a result of the reduction in dietary particle size is consistent with the results of Oryschak et al. (2002). A increase of ileal digestibility at a greater difference between particle size, $1000 \mathrm{vs}$ $500 \mu \mathrm{m}$, was observed by Lahaye et al. (2004). In the presented study, the F diet was a low-excretion diet since it reduced not only nutrient excretion in faeces, but also urea $\mathrm{N}$ excretion. Supplementing the finely ground diet with $\beta$-glucanase and xylanase increased protein digestibility, but not $\mathrm{N}$ retention, and affected the performance of pigs from the FE group to a small extent. 


\section{CONCLUSIONS}

Reduction of particle size from 800 to $500 \mu \mathrm{m}$ in pig diets allows for a decrease in dietary protein content and reduction of nitrogen excretion without deterioration of growth performance or carcass quality. Further supplementation with carbohydrases has little effect.

\section{REFERENCES}

Baidoo S.K., Liu Y.G., Yungblut D., 1998. Effect of microbial enzyme supplementation on energy, amino acid digestibility and performance of pigs fed hulless barley based diets. Can. J. Anim. Sci. 78, 625-631

Lahaye L.L., Ganier P., Thibault J.N., Sève B., 2004. Technological processes of feed manufacturing affect protein endogenous losses and amino acid availability for body protein deposition in pigs. Anim. Feed Sci. Tech. 113, 141-156

Mavromichalis I., Hancock J.D., Senne B.W., Gugle T.L., Kennedy G.A., Hines R.H., Wyatt C.L., 2000. Enzyme supplementation and particle size of wheat in diets for nursery and finishing pigs. J. Anim. Sci. 78, 3086-3095

Oryschak M.A., Simmins P.H., Zijlstra R.T., 2002. Effect of dietary particle size and carbohydrase and/or phytase supplementation on nitrogen and phosphorus excretion of grower pigs. Can. J. Anim. Sci. 82, 533-540

Wondra K.J., Hancock J.D., Behnke K.C., Stark C.R., 1995. Effects of mill type and particle size uniformity on growth performance, nutrient digestibility, and stomach morphology in finishing pigs. J. Anim. Sci. 73, 2564-2573

\section{STRESZCZENIE}

\section{Rozdrabnianie paszy i dodatek enzymów jako czynniki poprawiające wykorzystanie białka z mieszanek o obniżonej zawartości białka dla świń}

32 wieprzki żywiono od ok. 28 do $100 \mathrm{~kg} \mathrm{m.c.} \mathrm{dietą} \mathrm{grubo} \mathrm{zmieloną} \mathrm{(} 800 \mu \mathrm{m}$ ) o normalnej zawartości białka (dieta C) oraz dwiema dietami drobno zmielonymi $(500 \mu \mathrm{m})$ o zawartości białka obniżonej o ok. 8\%, z których jedna była nie uzupełniona, a druga uzupełniona glukanazą i ksylanazą (odpowiednio dieta F i FE). Mielenie (dieta F vs C) i uzupełnienie enzymami (dieta FE vs F) spowodowało zwiększenie strawności białka, a mielenie także strawności energii. Świnie żywione dietami F i FE wydalały mniej azotu i miały taką samą retencję $\mathrm{N}$ jak zwierzęta żywione dietą $\mathrm{C}$ o wyższej zawartości białka. Rodzaj diety nie wpłynął na przyrosty, wykorzystanie paszy, zawartość mięsa w tuszy oraz zawartość białka i tłuszczu w Musculus longissimus dorsi. Wykorzystanie białka na przyrost było lepsze w grupach F i FE niż w C. 